\title{
O ENSINO DE LíNGUA PORTUGUEga NA PANDEMHA OS DESAFIOS DA DOCÊNCIA NO CONTEXTO REMOTO
}

\author{
THE TEACHING OF PORTUGUESE LANGUAGE DURING THE PANDEMIC:
} THE CHALLENGES OF TEACHING IN THE REMOTE CONTEXT

\section{Ana Patrícia Sá Martins}

Doutora em Linguística Aplicada pela Universidade do Vale do Rio dos Sinos (Rio Grande do Sul/Brasil).

Professora na Universidade Estadual do Maranhão (Maranhão/Brasil).

E-mail: anamartins1@professor.uema.br

\section{Hilmara Rocha da Silva}

Licenciada em Letras pela Universidade Estadual do Maranhão (Maranhão/Brasil).

E-mail: hilmarapontes07@gmail.com

Recebido em: 13 de abril de 2021

Aprovado em: 1 de julho de 2021

Sistema de Avaliação: Double Blind Review

RPR |a. 18|n. 3 |p. 157-180| set./dez. 2021

DOI: https://doi.org/10.25112/rpr.v3.2589 


\section{RESUMO}

O presente artigo visa a analisar como tem ocorrido o ensino de Língua Portuguesa e quais as dificuldades enfrentadas pelos docentes com relação ao uso das tecnologias digitais no contexto pandêmico. Nesse sentido, desenvolvemos uma pesquisa qualitativa, de caráter exploratório, do tipo estudo de caso, tendo como instrumento para geração de dados um formulário construído na plataforma Google Forms, para os docentes da rede pública estadual na cidade de Balsas, região Sul do estado do Maranhão. Sob o aporte teórico da Análise Dialógica do Discurso (ALBUQUERQUE, 2007; BRAIT, 2014), mais especificadamente, através das categorias valoração e polifonia (BAKHTIN, 2011; VOLOSHINOV, 1981; WHITE, 2005), e dos estudos dos Multiletramentos nas práticas sociais (ROJO, 2013; BARTON; LEE, 2015), nossos dados revelaram a incipiente apropriação didática dos docentes quanto aos recursos tecnológicos digitais e, consequentemente, a carência de formações continuadas para o exercício de suas práticas sociais letradas no âmbito escolar. Além disso, nossas análises apontam as dificiculdades que professores e alunos têm sofrido com as mudanças constantes impostas pelo contexto de ensino remoto com a pandemia viral do coronavírus.

Palavras-chave: Ensino de Língua Portuguesa. Tecnologias Digitais. Impactos da Pandemia.

\section{ABSTRACT}

The present article aims to analyze how the teaching of Portuguese Language has been occurring and what are the difficulties faced by teachers regarding the use of digital technologies in the pandemic context. In this regard, we developed a qualitative, exploratory research, of a case study type, using as an instrument for data generation a form built in the Google Forms platform, for teachers from the public state school system in the city of Balsas, southern region of the state of Maranhão. Under the theoretical support of the Dialogical Discourse Analysis (ALBUQUERQUE, 2007; BRAIT, 2014), more specifically, through the categories valuation and polyphony (BAKHTIN, 2011; VOLOSHINOV, 1981; WHITE, 2005), and the studies of Multiliteracies in social practices (ROJO, 2013; BARTON; LEE, 2015), our data revealed the teachers' incipient didactic appropriation of digital technological resources and, consequently, the lack of continuing education for the exercise of their social literate practices at school environment. Furthermore, our analyses point to the difficulties that teachers and students have been experiencing with the constant changes imposed by the remote teaching context with the coronavirus viral pandemic. Keywords: Portuguese Language Teaching. Digital Technologies. Pandemic Impacts. 


\section{INTRODUÇão}

A constante evolução tecnológica ocorrida na sociedade tem provocado transformações significativas em nossas práticas letradas. A cada dia, são lançados inúmeros programas e novos aplicativos que facilitam o uso das tecnologias no âmbito social. Essa evolução tem provocado um crescente e rápido desenvolvimento tecnológico que vem ganhando espaço em todos os setores e áreas da sociedade.

Intensificada pelo contexto pandêmico, a influência das tecnologias digitais em nossas práticas sociais letradas desencadeou também uma urgente transformação nas relações de ensino-aprendizagem, nas diferentes realidades socioeconômicas. Ninguém ficou imune a essa radical mudança no modo de (com) viver!

Ao longo da última década, inúmeros trabalhos científicos foram publicados com o objetivo de discutir e incentivar o diálogo das tecnologias digitais sob uma perspectiva multiletrada nas escolas. Entrentanto, em meio à necessidade do ensino remoto como garantia do direito à educação, os sistemas de ensino vêm adicioando mais e mais competências e habilidades aos professores, os quais vão sendo sobrecarregados com atividades a serem desenvolvidas num modus operandi que não Ihes foi oportunizado adequadamente. Isto é, de modo abrupto (e até assustador!), os docentes são exigidos a se reiventar na educação com o uso didático das tecnologias digitais, porém sem formações para tal.

A partir dessa situação, as seguintes inquietações nortearam nossa pesquisa: como tem ocorrido o ensino de Língua Portuguesa e quais as dificuldades enfrentadas com relação ao uso das tecnologias no contexto pandêmico? Desta forma, empreendemos um estudo de caso com professores de uma escola da rede pública estadual, situada na cidade de Balsas, região sul do Maranhão, que, assim como em todo território nacional, desde março de 2020, enfrenta momentos turbulentos ocasionados pela chegada da pandemia do novo coronavírus, quando professores e estudantes precisaram se adequar a uma nova modalidade de ensino até então não explorada pela maioria desses.

Desse modo, apresentamos o presente artigo, sistematizado em cinco seções, além da já explicitada Introdução. Inicialmente, pontuamos nossas bases teóricas que nortearam a referida pesquisa, discutindo as perspectivas dos Multiletramentos no ensino, bem como a concepção dialógica da língua/linguagem em práticas sociais, a partir das ideias do Círculo de Bakhtin. Em seguida, abordaremos os procedimentos metodológicos empreendidos para o desenvolvimento da pesquisa. Posteriormente, analisamos os dados gerados a partir dos discursos dos professores de Língua Portuguesa acerca de suas dificuldades no contexto de ensino remoto. Por fim, tecemos nossas considerações finais e elencamos as referências que sustentaram nosso trabalho. 


\section{MULTILETRAMENTOS E ENSINO SOB O OLHAR DIALÓGICO DA LINGUAGEM}

Argumentar a inserção dos Multiletramentos nas práticas sociais tem sido um debate necessário, dado que vivemos em uma sociedade cada vez mais conectada pelas redes de comunicação e de informação. Os cenários digitais que abrangem as interações humanas na web são diversificados e, na atualidade, esses ambientes vêm se mostrando mais fecundos para fomento de investigações que abarcam a linguagem e tecnologia, uma vez que mostram a amplitude que as práticas discursivas ganham quando difundidas por esse meio.

Segundo Rojo (2013, p. 14), a modernidade e os textos contemporâneos dispõem de novos desafios aos letramentos e às teorias, conduzindo a uma educação linguística em que os alunos possam perceber o pluralismo cultural. Para tal, a autora alega que antes é necessário inserir no âmbito educacional projetos futurísticos, sob três dimensões: a primeira é a diversidade produtiva, ou a desempenhada no âmbito do trabalho; a segunda, o pluralismo cívico, ou o trabalhado no âmbito da cidadania; e, por último, as identidades multifacetadas, que fazem parte da vida social:

O conceito de multiletramentos, articulado pelo Grupo de Nova Londres, busca justamente apontar, já de saída, por meio do prefixo 'multi', para dois tipos de 'múl-tiplos' que as práticas de letramentos contemporâneas envolvem, por um lado, a multiplicidade de linguagens, semioses e mídias envolvidas na criação de significa-ção para os textos multimodais contemporâneos e, por outro, a pluralidade e a di-versidade cultural trazida pelos autores/leitores contemporâneos a essa criação de significação. (ROJO, 2013, p. 14).

Segundo Rojo e Moura (2019, p. 1), o termo multiletramentos surgiu no final do século 20, em 1996, através de um grupo de pesquisadores ingleses, americanos e australianos, reunidos na cidade de Nova Londres (EUA), para discutir as mudanças que os textos vinham sofrendo e, consequentemente, os letramentos.

Os pesquisadores do GNL ressaltavam que os textos, em parte devido ao impacto das novas mídias, estavam mudando e já não mais eram essencialmente escritos, mas se compunham de uma pluralidade de linguagens, que eles denominaram multimodalidade. Para eles, o mundo estava mudando aceleradamente na globalização: explosão das mídias, diversidade étnica e social das populações em trânsito, multiculturalidade. Isso tinha impacto não somente nos textos, que se tornavam cada vez mais multimodais, mas também na diversidade cultural e linguística das populações, o que implicaria mudanças necessárias na educação para o que chamaram de multiletramentos (ROJO; MOURA, 2019, p. 14, grifo dos autores). 
Diante das rápidas transformações culturais que envolvem os letramentos, fazem-se presentes não somente as mudanças nos processos de leitura e escrita, mas também no uso dos diferentes suportes digitais, uma vez que o surgimento de novas tecnologias acaba trazendo à tona a mediação e transformação de nossas comunidades. De acordo com os autores, compreendemos os multiletramentos como as atividades que envolvem o uso da linguagem dentro das práticas sociais de leitura e escrita.

Kleiman (2007, p. 04) defende os estudos do letramento como uma concepção de leitura e escrita agindo como agentes das práticas discursivas, ou seja, com funções inseparáveis e que agem juntas para o desenvolvimento do contexto. Sendo que essa aprendizagem irá se concretizar por meio da experiência de cada pessoa individualmente e, nessa junção, partindo do social, vão além daquilo que definimos como espaço formal de ensino, abrindo caminho para inclusão de uma nova modalidade. Ou seja, a vida cotidiana é permeada de leitura e escrita, uma vez que atividades do dia a dia são caracterizadas como práticas de letramentos, pois possuem padrões comuns de leitura e escrita em seu planejamento, como também explicam Barton e Lee (2015):

Em outros domínios da vida, também existem práticas sociais identificáveis em que o letramento é imprescindível. No domínio da educação, por exemplo, atividades como fazer um trabalho escolar ou preparar uma apresentação envolvem uma ampla gama de práticas de letramento. De igual modo, na esfera do trabalho, não importa se é um médico ou um atendente de algum serviço de atendimento ao cliente, o dia de trabalho da maioria das pessoas implica o uso de leitura e escrita. (BARTON; LEE, 2015 p. 40).

Compreendemos, portanto, que essa concepção de multiletramentos abrange uma infinidade de práticas sociais que envolvem o ato de ler e escrever. E que, portanto, devido à diversidade das práticas de leitura e escrita que circulam atualmente na sociedade, tomamos conhecimento da multimodalidade e multissemiose da linguagem, uma vez que estamos tratando da existência não de uma, mas de várias práticas letradas que circulam na sociedade.

Segundo Rojo (2009, p. 107), "um dos objetivos principais da escola é justamente possibilitar que seus alunos possam participar das várias práticas sociais que se utilizam da leitura e da escrita (letramentos) na vida da cidade, de maneira ética, critica e democrática", uma vez que, como em qualquer atividade humana, a questão dos multiletramentos acontece de forma que o indivíduo autoaprende e passa a desenvolver suas ideias e seu agir, através da relação social com o meio (colegas, educador e sociedade).

Esse processo de multiletramentos na escola nos leva a uma reflexão acerca da forma que ocorrem os processos de aprendizagem, e que levam em conta aspectos pedagógicos, ações de como ensinar, planejamento, capacidade discursiva e práticas pedagógicas em multiletramentos, usadas no ensino 
médio. Essas práticas se concretizam de maneira que possam resolver problemas, tais como desistência, reprovação e fracasso escolar, fazendo com que estudantes se insiram num contexto de ensinoaprendizagem que leva a um melhor desenvolvimento de sua vida social.

Diante do enfrentamento da pandemia do novo coronavírus (Covid-19), o estado do Maranhão, através da Secretária de Estado da Educação (SEDUC), decidiu por dar continuidade ao processo de ensino-aprendizagem dos estudantes por meio de plataformas digitais e por meios eletrônicos, com a gravação de aula e veiculação em canais de TVs abertos e rádios, na intenção de que um público maior tenha acesso a essa aprendizagem.

Quando falamos em processos de aprendizagem, não podemos deixar de citar o uso dos gêneros digitais em sala de aula, porque ao trabalhar gêneros discursivos, trabalhamos uma ferramenta incontável e de fácil adaptação à realidade ou formas comunicativas. E com o advento da tecnologia, observamos o surgimento de novos gêneros e alguns já existentes passam a ganhar diferentes formas, o que modifica dia após dia a relação consolidada entre autor e leitor.

Quanto ao surgimento e presença dos gêneros digitais e multimodais, a Base Nacional Comum Curricular (BNCC, 2018) tem fomentado a inserção destes nas práticas de ensino-aprendizagem. Sabemos que a BNCC é um documento que visa nortear o que deve ser ensinado nas escolas, tanto públicas como particulares, no decorrer dos anos em que se encontram na Educação Básica. De acordo com a BNCC, na seção 5.1, Área de Linguagens e suas Tecnologias, em competências especificas I, é importante:

Compreender o funcionamento das diferentes linguagens e práticas culturais (artísticas, corporais e verbais) e mobilizar esses conhecimentos na recepção e produção de discursos nos diferentes campos de atuação social e nas diversas mídias, para ampliar as formas de participação social, o entendimento e as possibilidades de explicação e interpretação crítica da realidade e para continuar aprendendo. (BNCC, 2018, p. 493).

A citação acima trata de uma competência específica que aborda a questão de que no decorrer do Ensino Médio os jovens precisam desenvolver uma certa compreensão e análise mais aprofundada e sistemática do funcionamento das diferentes linguagens. Ou seja, prevê que os estudantes possam explorar e perceber os modos como as diversas linguagens se combinam de maneira híbrida em textos complexos e multissemióticos, para que possam ter a possibilidade de aprender e atuar socialmente, conduzindo-os a articular conhecimentos.

Nesse sentido, a BNCC, na seção 5.1.2., Língua Portuguesa, prescreve que:

Ao chegar ao Ensino Médio, os estudantes já têm condições de participar de forma significativa de diversas práticas sociais que envolvem a linguagem, pois, além de 
dominarem certos gêneros textuais/discursivos que circulam nos diferentes campos de atuação social considerados no Ensino Fundamental, eles desenvolveram várias habilidades relativas aos usos das linguagens. Cabe ao Ensino Médio aprofundar a análise sobre as linguagens e seus funcionamentos, intensificando a perspectiva analítica e crítica da leitura, escuta e produção de textos verbais e multissemióticos, e alargar as referências estéticas, éticas e políticas que cercam a produção e recepção de discursos, ampliando as possibilidades de fruição, de construção e produção de conhecimentos, de compreensão crítica e intervenção na realidade e de participação social dos jovens, nos âmbitos da cidadania, do trabalho e dos estudos. (BNCC, 2018, p. 500).

O documento trata do ponto de vista das práticas contemporâneas de linguagem, no Ensino Médio, sobre a cultura digital, as culturas juvenis, os novos letramentos e os multiletramentos, os processos colaborativos, as interações e atividades que têm ganhado lugar nas mídias e redes sociais, e vêm fazendo com que os jovens produzam cada vez mais através desses meios, que têm ocupado na atualidade um lugar muito importante para que haja essa construção social e até mesmo textual.

Nesse sentido, argumentamos a relevância de um processo de ensino sob a perspectiva dos multiletramentos que compreenda a língua/linguagem através da perspectiva social e dialógica nas interações verbais, no que concerne a essas práticas letradas socialmente na atualidade e à multimodalidade da língua na formação dos textos na contemporaneidade.

A língua/linguagem enquanto concepção dialógica é compreendida no viés de uma perspectiva social, na qual os sujeitos, por meio das interações verbais, constituem um processo linguístico social. Desta forma, ela é social e o sujeito que a integra também o é, pois ele está inserido nesse processo dialógico. Assim sendo, para que possamos de antemão entender o dialogismo, precisamos pensar em enunciado, interação, signo ideológico e gêneros do discurso, em razão de precisarmos entender o enunciado, porque os sujeitos falam usando enunciados, e estes, por sua vez, se dão através da interação que é a base para as relações dialógicas.

A Análise Dialógica do Discurso (ADD) surge como instrumento teórico-metodológico que se ocupa da investigação dos sentidos concretos de textos, tanto orais como escritos, produzidos nas mais diversas esferas de atividade humana e trabalha a análise a partir das relações dialógicas desses discursos com outros discursos e ainda a relação do discurso com as mais variadas instâncias entre sujeitos sóciohistóricos. Segundo Brait (2014, p. 10):

Uma teoria/análise dialógica do discurso, sem configurar uma proposta fechada e linearmente organizada, constituem de fato um corpo de conceitos, noções e categorias que especificam a postura dialógica diante do corpus discursivo, da metodologia e do pesquisador. A pertinência de uma perspectiva dialógica se dá pela análise 
das especificidades discursivas constitutivas de situações em que a linguagem e determinadas atividades se interpenetram e se interdefinem, e do compromisso ético do pesquisador com o objeto, que, dessa perspectiva, é um sujeito histórico. (BRAIT, 2014, p. 29).

Os estudos da Análise Dialógica do Discurso se relacionam a esse trabalho por esta ser uma teoria que auxilia na compreensão de efeitos de sentido do texto e contribuem na elaboração de construtivos linguísticos que atendem as mais diversas esferas da atividade humana. Albuquerque (2007) aborda a realidade escolar como promovedora de aprendizagens tradicionais e que não são capazes de atingir as perspectivas do letramento, em uma realidade que precisa ser mudada, e afirma que:

As práticas de leitura e produção de textos desenvolvidas na escola, relacionadas a um 'letramento escolar', não se adequariam, conforme certas expectativas, ao desenvolvimento socioeconômico-cultural de nossa sociedade, em que os indivíduos convivem em contextos em que a escrita se faz presente de forma mais complexa. 0 ensino tradicional de alfabetização em que primeiro se aprende a 'decifrar um código' a partir de uma sequência de passos/etapas, para só depois se ler efetivamente, não garante a formação de leitores/escritores. (ALBUQUERQUE, 2007, p. 18).

Em sua maioria, nossas escolas acabam por evidenciar apenas a prática de alfabetização. Entretanto, para que haja um domínio de uma língua, faz-se necessária uma relação intensa com a participação social, uma vez que através dela se efetiva a comunicação, onde o homem passa a expressar e a defender pontos de vista, recebe acesso à informação e constitui suas visões de mundo e conhecimento. 0 estudo da língua materna, nesse contexto, possui grande valor educacional na formação do saber, pois provoca uma grande troca de conhecimentos, experiências e leituras de mundo, funcionando como um meio de comunicação, criando acesso a diferentes formas de pensar, agir e idealizar a sociedade.

De acordo com Bakhtin (2011), os sujeitos sociais, ao participarem das interações, fazem usos dos signos linguísticos, organizando-os na forma de textos que são construídos com base na intenção do interlocutor e na realização dessa intenção. Ou seja, através dessa premissa, determina a distinção no entendimento do texto nos planos linguísticos e discursivos, pois mesmo que por trás da construção textual possua todo um sistema linguístico, o autor afirma que as relações se determinam no uso dos elementos do sistema da língua. E explica sua tese através da premissa de que por meio do texto e com relação a sua conexão com a vida, é possível o desenvolvimento de um estudo do ser social e de suas ações.

O termo polifonia, inicialmente criado pelo filósofo Mikhail Bakhtin (1895-1975), traz em sua representatividade a pluralidade ou multiplicidade de vozes alocadas no texto. Ele afirma: 
Cada conjunto verbalizado grande e criativo é um sistema de relações muito complexo e multiplanar. Na relação criadora com a língua não existem palavras sem voz, palavras de ninguém. Em cada palavra há vozes às vezes infinitamente distantes, anônimas, quase impessoais (as vozes dos matizes lexicais, dos estilos etc.), quase imperceptíveis, e vozes próximas, que soam concomitantemente. (BAKHTIN, 2003, p. 330).

A questão da polifonia ou multiplicidade de vozes surge quando o autor inicia suas concepções relacionadas ao romance. Segundo Bakhtin, o autor-criador (que é aquele que não é por princípio uma instância narrativa abstrata, ou melhor, o narrador), nada mais é do que uma consciência da consciência, pela qual o autor-criador sabe mais do que seu personagem. Ou para que haja melhor compreensão, o autor é para o personagem o que o outro é para mim; ou seja, é o ponto de vista do outro que me dá acabamento, no universo bakhtiniano nenhuma voz, jamais, fala sozinha. E isso acontece não pela perspectiva de estarmos socialmente expostos a influências do mundo externo, mas por conta da natureza da linguagem em se desenvolver inelutavelmente em dupla.

Se eu mesmo sou um ser acabado e se o acontecimento é algo acabado, não posso nem viver nem agir: para viver devo estar inacabado, aberto para mim mesmo - pelo menos no que constitui o essencial da minha vida - devo ser para mim mesmo um valor ainda por-vir, devo não coincidir com a minha própria atualidade. (BAKHTIN apud TEZZA, 2001, p. 284).

O fragmento acima afirma que só podemos nos imaginar, por inteiro, sob o olhar do outro, uma vez que a minha palavra de forma imprescindivel está condiciona pelo olhar de fora, é o outro que trará o sentido e acabamento. E na presença dessa multiplicidade de vozes, tanto em romances como em textos em geral, elas possuem a função de marcar diferentes pontos de vista acerca de um mesmo assunto. Ou seja, Bakhtin define o termo voz como uma consciência falante que se faz presente nos enunciados, defende ainda como uma consciência que não é neutra, isto é, está sempre refletindo as percepções de mundo, juízo e valores, ressalta ainda que a polifonia se manifesta em textos que deixam distinguir outras vozes. Nessa concepção, o outro desempenha papel fundamental na construção de sentidos.

Diante do exposto, entendemos que analisar os discursos dos professores de Língua Portuguesa que estão lecionando no contexto de ensino remoto sob o prisma da Análise Dialógica do Discurso, bem como sob o aporte dos estudos dos Multiletramentos no ensino, pode nos possibilitar visualizar perspectivas críticas e situadas acerca das dificuldades enfrentadas pelos docentes na pandemia e, assim, pontuar (novos) caminhos didáticos para construção e desenvolvimento de processos de ensino-aprendizagem que, de fato, permitam apropriações responsivas e responsáveis das tecnologias digitais durante e póspandemia. 


\section{PROCEDIMENTOS METODOLÓGICOS}

A presente pesquisa caracteriza-se como um estudo de caso, com abordagem qualitativa e de caráter exploratório. Nesse processo, conforme Minayo (2001, p. 14), o pesquisador realizará a geração de dados e esse material o auxiliará na construção do seu conhecimento sobre o seu tema de pesquisa, com a finalidade de que na construção do seu trabalho saiba explicar e discutir a temática por ele pesquisada, trabalhando aspectos da realidade e centrando-se na compreensão e explicação da dinâmica das relações sociais.

À vista disso, nosso objetivo é analisar as dificuldades dos professores de Língua Portuguesa com as tecnologias digitais no processo ensino-aprendizagem durante o contexto pandêmico em uma escola pública da rede estadual na cidade de Balsas-MA. Nossos dados foram gerados a partir de um formulário construído no Google Form, contendo dez perguntas abertas e fechadas, disponibilizado aos professores de Língua Portuguesa via link no WhatsApp, durante os meses de agosto e setembro de 2020.

Para discussão e análises dos dados, utilizamos a categoria polifonia, que, de acordo com Brait (2020):

[...] é a posição do autor como regente do grande coro de vozes que participam do processo dialógico. Mas esse regente é dotado de um ativismo especial, rege vozes que ele cria ou recria, mas deixa que se manifestem com autonomia e revelem no homem um outro 'eu para si' infinito e inacabável. Trata-se de uma 'mudança radical da posição do autor em relação às pessoas representadas', que de pessoas coisificadas se transformam em individualidades. (BRAIT, 2020, p. 191, grifos da autora).

Assim sendo, a polifonia possui sua definição centrada pela convivência e pela interação, que ocorre em um mesmo espaço, com a participação de uma multiplicidade de vozes e consciências, onde essas vozes e consciência não são qualificadas pelo discurso do autor, são sujeitos que criam seus próprios discursos.

Utilizamos ainda a categoria valoração, uma vez que a valoração age como fruto da interação social e traz uma importante contribuição para essa pesquisa, posto que é pertencente à base ideológica, a qual, conforme Volochinov (1993, p. 224), trata-se da totalidade das reflexões e interpretações da realidade social e natural que acontecem no cérebro do homem, materializadas por meio de palavras, desenhos, diagramas ou outras formas sígnicas.

\section{OS DESAFIOS DA DOCÊNCIA NO CONTEXTO REMOTO}

Este trabalho teve como colaboradores da pesquisa professores de Língua Portuguesa alocados em uma escola de Ensino Médio, na cidade de Balsas, localizada na região sul do Maranhão, a qual é uma 
instituição que tem contribuído com a formação escolar de muitos jovens. Localizada na região central da cidade, é uma das principais escolas públicas com o público específico de Ensino Médio. A opção dessa escola como cenário da pesquisa deu-se em virtude de sua abrangência à população local, como também devido ao professorado, em sua grande maioria, lecionar nos dois turnos.

Conforme afirma Gauthier (1998), a escola deve ser vista além do lugar que socializa o saber metódico, mas também como um lugar de trabalho do professor, o qual depende, para se organizar e atender às suas demandas, de profissionais que atuem em seus diferentes espaços, de forma sustentada por conhecimentos e saberes construídos com base em diferentes teorias e experiências diversas. Dessa forma, escolhemos a escola por ser um lugar essencial para a sociedade, em razão de que por meio dela se formam e concretizam as relações sociais, e, assim, possamos investigar os desafios que essa nova modalidade de ensino tem imposto aos professores em tempos de pandemia.

Ressaltamos que, em visita à escola, conversamos com as diretoras que prontamente nos receberam e demonstraram empatia pela nossa proposta de pesquisa, colocando-se à disposição. Foi através das gestoras que tivemos acesso aos contatos do Whatsapp dos docentes de Língua Portuguesa. A escolha pelos docentes de Língua Portuguesa justifica-se por ser a área de formação das autoras, como também por ser o foco de investigação de seu grupo de pesquisa na graduação e pós-graduação stricto sensu.

A escola possui um total de 04 professores de Língua Portuguesa do Ensino Médio, os quais lecionam nos turnos matutino e vespertino. Enviamos o link do formulário para a pesquisa, intitulado "Os desafios do ensino de Língua Portuguesa com a utilização das tecnologias em período de pandemia". Após um mês de prazo para responderem às questões do formulário, 03 professores nos devolveram, e uma se absteve em responder, alegando: "Estou muito atarefada, pois possuo 18 salas de aulas on-line, e estou sobrecarregada. Tudo isso tem exigido muito dos professores, por isso acredito que outros professores, com carga horaria menor, podem responder a esse questionário de pesquisa". Respeitamos a justificativa da professora e, passemos agora às nossas análises.

No Quadro 1, sistematizamos a faixa etária dos docentes:

Quadro 1- Faixa etária dos docentes

\begin{tabular}{|c|c|}
\hline PROFESSOR (A): & RESPOSTA: \\
\hline A & 40 a 50 anos \\
\hline B & 50 a 60 anos \\
\hline C & 30 a 40 anos \\
\hline
\end{tabular}

Fonte: Elaborado pelas autoras. 
Como podemos notar, a escola conta com a contribuição de professores de Língua Portuguesa de variadas idades, o que pode implicar em distintas formações básicas na licenciatura e, consequentemente, perspectivas pedagógicas no processo de ensino-aprendizagem. Entendemos que essa diferença etária coopera para que se tenha diferentes niveis de conhecimento, que auxiliam positivamente na formação desses alunos, já que a profissão docente tem se realizado de forma bastante difícil, ainda mais nos tempos atuais, onde a sociedade em geral exige que os professores precisem ir além de suas obrigações do dia a dia, reivindicando que eles, além de cumprir suas funções, precisem intervir em situações geradas no campo social, ou seja, esses professores, além da prática pedagógica, precisam lidar com uma tarefa ainda mais complexa, que é a de acompanhar os processos de mudanças socias, culturais, políticas e educacionais.

Quadro 2- Formações de Pós-Graduação dos docentes

\begin{tabular}{|c|c|}
\hline PROFESSOR (A): & RESPOSTA: \\
\hline A & Língua Portuguesa com ênfase em gramática e literatura. \\
\hline B & Doutorado em Linguística Aplicada. \\
\hline C & Sim. \\
\hline
\end{tabular}

Fonte: Elaborado pelas autoras.

Quanto à formação na pós-graduação, apenas o professor C não especificou a área de conhecimento, ainda que ratificando a informação sobre possuir uma pós-graduação. Ao visualizarmos o quadro 2 , observamos que os docentes buscaram investir em sua formação acadêmica e profissional. Do ponto de vista de Wengzynski e Tozetto (2012, p. 4),

A formação continuada contribui de forma significativa para o desenvolvimento do conhecimento profissional do professor, cujo objetivo, entre outros, é facilitar as capacidades reflexivas sobre a própria prática docente elevando-a a uma consciência coletiva. A partir dessa perspectiva, a formação continuada conquista espaço privilegiado por permitir a aproximação entre os processos de mudança que se deseja fomentar no contexto da escola e a reflexão intencional sobre as consequências destas mudanças (WENGZYNSKI; TOZETTO, 2012, p. 04).

Além de possibilitar que o educador agregue conhecimento na vida de seus alunos e seja capaz de gerar transformação e impacto no contexto escolar, a formação continuada age como um ponto fundamental para a obtenção de novos conhecimentos e metodologias para facilitar no processo ensinoaprendizagem. 
Quadro 3- Tempo de atuação na docência

\begin{tabular}{|c|c|}
\hline PROFESSOR (A): & RESPOSTA: \\
\hline A & 5 a 10 anos \\
\hline B & Mais de 20 anos \\
\hline C & 5 a 10 anos \\
\hline
\end{tabular}

Fonte: Elaborado pelas autoras.

Quanto ao tempo de atuação na docência, percebemos no quadro 3 que todos os docentes possuem mais de cinco anos de experiência, o que pode corroborar a aquisição de múltiplos conhecimentos, sobretudo, numa perspectiva dialética entre teoria e prática ao longo da caminhada pedagógica de aprendizado com seus alunos.

Quadro 4- Avaliação dos docentes quanto à qualidade do acesso à internet na sua esfera familiar

\begin{tabular}{|c|c|}
\hline PROFESSOR (A): & RESPOSTA: \\
\hline A & Regular \\
\hline B & Bom \\
\hline C & Bom \\
\hline
\end{tabular}

Fonte: Elaborado pelas autoras.

$\mathrm{Na}$ questão 4, foi solicitado aos docentes que avaliassem a qualidade do acesso à internet na sua esfera familiar, considerando que o contexto de ensino remoto exigiu dos professores a prática profissional dentro de suas residências. Considerando que as opções de respostas no formulário enviado aos docentes eram: regular, bom, excelente, é possível observamos no quadro 4 que nenhum dos nossos colaboradores da pesquisa avalia como excelente e sem problemas a qualidade de acesso à internet em suas residências.

Tendo em vista a perspectiva dialógica e responsiva da linguagem, entendemos que as valorações sinalizadas pelos docentes revelam o esforço de cada professor em continuar seu ofício no contexto pandêmico. Ademais, percebemos como foi transferida aos professores uma responsabilidade que não era (somente) deles, para a viabilidade do ensino, pois, enquanto gestores políticos noticiam que estão dando suporte para a efetivação da educação, com distribuição de chips com internet a alunos, por outro lado, há o silêncio e ausência de estratégias políticas e pedagógicas (e diríamos até psicológicas) no assessoramento aos professores, uma vez que o ensino pandêmico tem nos revelado que não somente os alunos possuem precariedade no acesso à internet, mas os professores também. 
Quadro 5- Respostas dos docentes quanto à tomada de decisão dentro da escola para inclusão do ensino médio a distância e sua adaptação para uso das novas plataformas de ensino

\begin{tabular}{|c|l|}
\hline PROFESSOR (A): & \multicolumn{1}{c|}{ RESPOSTA: } \\
\hline A & $\begin{array}{l}\text { A pandemia trouxe uma nova realidade para a comunidade escolar, mudou a rotina } \\
\text { de alunos e professores. Foi preciso reorganizar as atividades, adequar conteúdos à } \\
\text { nova metodologia de ensino e aos poucos ir aprendendo com cada situação. }\end{array}$ \\
\hline B & $\begin{array}{l}\text { A tomada de decisão foi problemática, uma vez que ocorreu às pressas, de forma } \\
\text { inesperada e com incumbência de usarmos recursos que, se não desconhecidos, } \\
\text { descolados dos hábitos escolares. Para mim, o processo de adaptação foi (e continua } \\
\text { sendo) assustador, pois foi preciso aprender a manejar ferramentas tecnológicas } \\
\text { "estranhas" (dificeis e variadas) ao nosso costume. Há ferramentas que até hoje não } \\
\text { consigo operar satisfatoriamente. }\end{array}$ \\
\hline C & $\begin{array}{l}\text { Foi preciso conhecer melhor o Google Forms e o Google sala de aula. Mudar de } \\
\text { celular para processamento dos aplicativos e memória. }\end{array}$ \\
\hline
\end{tabular}

\section{Fonte: Elaborado pelas autoras.}

Nas respostas da pergunta de número 5 (cinco), conseguimos compreender que os professores tiveram dificuldades com essa tomada de decisão pela continuidade das aulas sendo ministradas remotamente. 0 professor A enfatiza o fato de que a pandemia trouxe uma nova realidade para a comunidade escolar, o professor B descreve a tomada de decisão como problemática, por ter ocorrido de forma inesperada, e completa ainda falando sobre a dificuldade com a adaptação, caracterizando-a como assustadora. 0 professor $C$ retrata que precisou conhecer a fundo novas ferramentas tecnológicas, e que ainda houve a necessidade de trocar o seu aparelho celular para que suportasse o processamento de aplicativos.

Assim sendo, nós, enquanto sociedade, devemos nos preocupar com esses dados, já que os indivíduos têm suas práticas sociais letradas permeadas pelo uso das tecnologias em todos os setores da sociedade, recursos estes que requerem conhecimentos específicos (multiletramentos), sobretudo quanto ao viés didático, para que sejam efetivadas as práticas letradas. A pandemia fez com que houvesse uma acelerada nesse processo, e isso nos mostra que necessitamos romper o paradigma de que a tecnologia é uma vilã para a educação e passarmos a tratá-la como mais uma integrante dentro do cenário educacional.

Inquestionavelmente, entendemos que esses professores constroem seus discursos a partir de visões/ações sociais, políticas e ideológicas das quais fazem parte. Nesse sentido, analisando as respostas: enquanto o professor $A$ declara que precisou de algum tempo para se organizar para uma 
adequação à nova metodologia e que passou a ir aprendendo com essa nova modalidade, o professor B mostra a sua insatisfação com isso, ou seja, ele está sendo obrigado a manejar, mas que ainda assim não consegue operar satisfatoriamente. Vemos posicionamentos axiológicos e valorativos frente ao que eles têm vivenciado com a nova forma de ensinar. Os docentes deixam claro que não é que a inserção das tecnologias na educação não seja importante, mas as julgam como algo totalmente desconecto da realidade que a escola antes vivenciava.

O professor C nos faz retomar a questão da não assistência governamental para esses professores, pois as políticas de assistência ao acesso à internet no âmbito escolar beneficiaram os alunos e não os professores, que também são agentes fundamentais no processo de educar. Conforme menciona o professor C, precisou tirar de seu próprio bolso para comprar equipamento para conseguir levar conhecimento a seus alunos, e dentro dessa resposta abre-se uma brecha para que esses professores desabafem sobre a falta de assistência tanto em material, infraestrutura, quanto a incentivo financeiro para dar continuidade a um trabalho efetivo na educação, e dentro dessa premissa eles acabam puxando para si uma culpa que não é deles, demonstrando uma transferência de responsabilidade.

Quadro 6- Sobre a participação dos docentes em alguma formação profissional para o uso didático das tecnologias digitais

\begin{tabular}{|c|c|}
\hline PROFESSOR (A): & RESPOSTA: \\
\hline A & Não houve formação profissional específica. \\
\hline B & Sim, cursos oferecidos pela Universidade Estadual do Maranhão. \\
\hline C & Não. \\
\hline
\end{tabular}

Fonte: Elaborado pelas autoras.

Nas respostas à pergunta de número 6 (seis), os professores A e $C$ relataram não ter recebido formação para uso das tecnologias para fins didáticos. E o professor $B$ afirmou que recebeu através de uma instituição de ensino superior na qual trabalha. De acordo com Delors (2003):

A qualidade de ensino é determinada tanto ou mais pela formação contínua dos professores, do que pela sua formação inicial... A formação contínua não deve desenrolarse, necessariamente, apenas no quadro do sistema educativo: um período de trabalho ou de estudo no setor econômico pode também ser proveitoso para aproximação do saber e do saber-fazer (DELORS, 2003, p. 160).

Conforme argumentado por Martins (2020), em sua tese de doutorado:

Aos estabelecimentos de ensino cabe observar, refletir e discutir acerca das transformações geradas pela exposição aos recursos digitais e pelo uso de novos meios 
de comunicação por parte dos futuros professores, no intuito de propor estratégias de ensino e aprendizagem que proporcionem formas mais efetivas e críticas de garantir sua autonomia diante do ambiente que o cerca (MARTINS, 2020, p. 30).

Aqui ela aborda a necessidade de que essas instituições estejam atentas para as mudanças na sociedade no que tange às transformações tecnológicas, e aborda uma questão para a qual, diante da análise dessa pergunta, vemos que não foi dada a devida atenção: a formação para uso desses meios em sala de aula. Com base nas respostas dos professores, percebemos que essa instituição escolar não ofereceu esse aporte para seus professores, pois um dos professores participantes responde que, apesar de ter tido uma formação, essa aconteceu em seu outro local de trabalho, no caso a universidade, e sabemos que trata-se de um público totalmente diferente, ou seja, aqui vemos que uma particularidade da vida pessoal e profissional do professor B influenciou em sua ação. É importante mencionarmos o fato de que esse mesmo professor cita em pergunta anterior que, mesmo tendo essa formação, não se sente habilitado a trabalhar esse tipo de ensino satisfatoriamente.

Partindo dessa afirmação, podemos compreender que para que o professor realize suas atividades é necessário oportunizar práticas formativas que dialoguem com suas reais necessidades didáticas. O contexto de ensino remoto revelou o quanto o diálogo com os recursos tecnológicos precisa ser mais criticamente proposto aos docentes, dada as novas maneiras de (com) vivermos e construirmos conhecimentos em nossas práticas sociais.

Quadro 7- Principais obstáculos enfrentados pelos docentes durante o ensino no contexto remoto

\begin{tabular}{|c|l|}
\hline PROFESSOR (A): & \multicolumn{1}{c|}{ RESPOSTA: } \\
\hline A & $\begin{array}{l}\text { Falta de domínio de alguns aplicativos de internet; falta de acesso à internet por parte } \\
\text { de alguns alunos; falta de computador e até mesmo de celular para acompanhar as } \\
\text { aulas; falta de interesse de alguns alunos que têm acesso às tecnologias; falta de } \\
\text { acompanhamento da família. O baixo poder aquisitivo da maioria dos estudantes da } \\
\text { rede pública é um dos principais motivos para que esses obstáculos ocorram. }\end{array}$ \\
\hline B & $\begin{array}{l}\text { A ruptura de um modelo presencial para um modelo à distância e a dificuldade no } \\
\text { uso das ferramentas. No primeiro caso, há um déficit de relação humana e suas } \\
\text { implicações nos afazeres pedagógicos. No segundo, a dificuldade de aprender a } \\
\text { operar os mecanismos tecnológicos em pouco tempo. }\end{array}$ \\
\hline C & $\begin{array}{l}\text { Dificuldade no engajamento dos alunos. Diminuição na quantidade e tamanho de } \\
\text { atividades. }\end{array}$ \\
\hline
\end{tabular}

Fonte: Elaborado pelas autoras. 
Nas respostas à pergunta de número 7 (sete), podemos conhecer as dificuldades enfrentadas por esse professores para ministrar aulas no período pandêmico. Conforme Martins et al. (2021), em e-book intitulado "Multiletramentos na Pandemia", que aborda que com poucos conhecimentos das tecnologias digitais em rede e, menos ainda, do seu potencial para o desenvolvimento dos processos de ensino e de aprendizagem, sem certeza alguma de como isso aconteceria, o professor imergiu nesse novo contexto, junto com os seus alunos. As autoras deixam bem claro no livro a aceleração nesse processo, pois levaria anos até que se pudesse implementar essa política da tecnologia na educação, mas que inesperadamente surgiu a pandemia e acelerou todo esse processo, e o professor se viu ali sem poder recorrer ao espaço físico que antes poderia.

Como podemos perceber, os professores revelam os desafios que passaram para implementar, ainda que de forma temporária, o ensino remoto na Educação Básica e, dentro dessa realidade, apresentam dificuldades vivenciadas por eles e pelos alunos. Conforme revelaram, além de precisar se reinventar nessa nova modalidade de ensino, mesmo com a incipiente competência técnica e didática para direcionar processos de aprendizagem em ambientes virtuais, os professores precisaram encarar as diferentes maneiras que seus alunos respondiam a seu aprendizado nessa nova modalidade, devido às distintas realidades econômicas e sociais de suas famílias.

Tais discursos nos revelam que as estratégias adotadas pela escola e pelos docentes expõem a desigualdade e as dificuldades enfrentadas pelos estudantes e professores de escolas públicas, e que problemas como o acesso limitado à internet, a falta de computadores e de espaço em casa, problemas sociais, sobrecarga de trabalho por parte do docente e baixa escolaridade dos familiares têm influenciado negativamente no sucesso dessa nova modalidade de ensino. 
Quadro 8- Avaliação dos docentes quanto à aprendizagem dos seus alunos

\begin{tabular}{|c|l|}
\hline PROFESSOR (A): & \multicolumn{1}{c|}{ RESPosTA: } \\
\hline A & $\begin{array}{l}\text { A aprendizagem não é a esperada, pois nem todos os alunos conseguem } \\
\text { acompanhar as aulas pelos motivos já citados na resposta anterior. Um outro } \\
\text { fator que colabora bastante para isso é a falta de intervenção do professor para } \\
\text { tirar as dúvidas do aluno no momento em que ocorre as aulas, já que a maioria } \\
\text { delas é gravada. }\end{array}$ \\
\hline B & $\begin{array}{l}\text { Avalio como uma aprendizagem deficiente. Os alunos costumam não executar } \\
\text { satisfatoriamente as tarefas que ministramos, e também costumam não } \\
\text { participar das avaliações de forma abrangente. Não é muito prático trabalhar } \\
\text { tecnologicamente: os alunos "se perdem" no processo de recepção e devolução } \\
\text { das atividades/trabalhos, pois a demanda é muito grande e praticamente ao } \\
\text { mesmo tempo. Há professores que trabalham muito com vídeos; particularmente } \\
\text { considero uma forma pobre: geralmente não passam de resumos fracos dos } \\
\text { conteúdos. }\end{array}$ \\
\hline C & \begin{tabular}{l} 
Moderada. \\
\hline
\end{tabular} \\
\hline
\end{tabular}

Fonte: Elaborado pelas autoras.

Nas respostas à pergunta de número 8 (oito), o professor $A$ descreve a aprendizagem como não esperada, uma vez que os alunos não conseguem acompanhar as aulas, por não possuírem acesso facilitado a essas tecnologias, cita ainda que a falta de intervenção do professor colabora para esse insucesso, pois a maioria das aulas são gravadas e enviadas a seus alunos. 0 professor $\mathrm{B}$ avalia como uma aprendizagem deficiente, pois, segundo o docente, nessa nova forma de ensinar, os alunos passam a não executar as atividades de forma satisfatória, não há praticidade no envio e recepção de atividades, e, pela demanda ser muito grande, professores acabam tendo que trabalhar muito com vídeos, os quais ele avalia como "uma forma pobre e que geralmente não passam de resumos fracos". O professor C limitou-se a responder com uma palavra: "moderada".

Os professores A e B enfatizam em seu discurso a frustação em como está sendo concretizada a aprendizagem dos alunos com as mudanças na forma de ensinar e aprender que a eles foram impostas com a chegada da pandemia. As dificuldades por eles relatadas acabam por ser um conjunto de ações deixadas de ser desenvolvidas no decorrer do tempo, a questão de amparo financeiro é uma condição que perpassa gerações e continua ou até mesmo se intensifica com o passar dos anos, a questão formação 
para uso das mídias também é algo que vem sendo deixado de lado, então, percebemos que esse conjunto de fatores desencadeia nas problemáticas encontradas na atual situação de ensino-aprendizagem.

Nos discursos desses professores fica nítido que as dificuldades relacionadas à implantação dessa nova modalidade de ensino atinge os dois lados, e que os resultados aqui encontrados dizem respeito à não qualificação desses professores, ao despreparo governamental no que diz respeito a implementar as tecnologias no âmbito escolar e que são uma série de fatores que juntos ocasionam nessas avaliações aqui feitas por esses docentes.

Quadro 9- Acerca das dificuldades para ensinar os componentes de Língua Portuguesa

\begin{tabular}{|c|l|}
\hline PROFESSOR (A): & \multicolumn{1}{|c|}{ RESPOSTA: } \\
\hline A & $\begin{array}{l}\text { Entendo que a dificuldade é a mesma para qualquer componente. Porém, é } \\
\text { necessário se reinventar diariamente para oferecer sempre o melhor para } \\
\text { o aluno, mesmo não havendo muitas vezes um feedback. É fundamental } \\
\text { também que o Governo continue implementando ações que visem estruturar } \\
\text { cada vez mais o ensino da rede estadual, oferecendo assim uma educação } \\
\text { de maior qualidade. }\end{array}$ \\
\hline B & $\begin{array}{l}\text { As habilidades de leitura e produção textual. Essas habilidades requerem } \\
\text { um acompanhamento altamente pessoal, presencial e contínuo. Não há a } \\
\text { menor possibilidade de você acompanhar a produção das turmas na base } \\
\text { do ler/reler; fazer/refazer o texto, sem contar com um problema cultural dos } \\
\text { alunos: de modo geral, eles não aceitam o trabalho de ler várias vezes um } \\
\text { texto, nem o de correção, ajuste/reajuste do texto. }\end{array}$ \\
\hline C & $\begin{array}{l}\text { Produção Textual. Pois é mais difícil orientar o aluno a distância. Prefiro ler o } \\
\text { texto de cada um juntamente com o aluno e indicar as correções necessárias. }\end{array}$ \\
\hline
\end{tabular}

Fonte: Elaborado pelas autoras.

Nas respostas à pergunta de número 9 (nove), o professor $A$ afirma que a dificuldade seja a mesma para qualquer componente. Já os professores B e C alegam haver maiores dificuldades nas habilidades de leitura e produção textual. $O$ professor $B$ explica que são habilidades que requerem um acompanhamento altamente pessoal, presencial e contínuo, enquanto o professor $C$ relata que seja difícil orientar o aluno a distância, preferindo ler o texto pessoalmente e indicar as correções necessárias.

E recordando o questionamento anterior, vemos se efetivar aquilo abordado anteriormente, quando os professores julgam como não esperada, deficiente e moderada. Aqui os professores relatam a dificuldade em ambos os componentes, defendem que, para que seja efetivado como realmente deve ser, esses 
componentes precisam ser desenvolvidos com uma proximidade entre professor e aluno, coisa que para eles essa nova modalidade de ensino os tirou.

Quadro 10- Avaliação dos docentes quanto a lecionar em período de pandemia com uso das tecnologias digitais e possiveis aprendizagens com essa experiência

\begin{tabular}{|c|l|}
\hline PROFESSOR (A): & \multicolumn{1}{c|}{ RESPOSTA: } \\
\hline A & $\begin{array}{l}\text { Apesar de todas as dificuldades enfrentadas, considero uma experiência } \\
\text { marcante, pois como professor sou desafiado diariamente a conhecer novas } \\
\text { ferramentas tecnológicas para facilitar o processo de ensino-aprendizagem. } \\
\text { Acredito que a partir dessa experiência, muitas práticas pedagógicas adotadas } \\
\text { nesse período serão utilizadas no dia a dia em sala de aula. }\end{array}$ \\
\hline B & $\begin{array}{l}\text { Particularmente não gosto. Faço o que posso e não creio que as tecnologias } \\
\text { digitais "roubem" o dia a dia da minha profissão. Se o aluno não se habituar a } \\
\text { lidar com os textos. Os textos são sujeitos com ideologias, intenções, história, } \\
\text { sentimentos; são sujeitos que tomam decisões; sujeitos que requerem } \\
\text { posicionamentos de quem os lê, conforme aprendemos com Bakhtin. }\end{array}$ \\
\hline C & $\begin{array}{l}\text { Ém pouco desgastante porque a todo momento chegam solicitações dos } \\
\text { alunos e da direção. O que irá agregar é que penso em incorporar alguns } \\
\text { aplicativos no cotidiano presencial. }\end{array}$ \\
\hline
\end{tabular}

\section{Fonte: Elaborado pelas autoras.}

Nas respostas à pergunta de número 10 (dez), quando lhes foi perguntado como avaliavam a experiência de lecionar em período de pandemia, o professor $A$ julga que, apesar de todas as dificuldades enfrentadas, é uma experiência marcante e que a partir dessa experiência aplicará muitas dessas práticas em seu dia a dia em sala de aula. O professor B revelou não haver gostado da experiência e que não acredita que as tecnologias roubem o dia a dia da sua profissão. 0 professor $C$ avaliou a experiência como desgastante, pois a todo momento chegam solicitações tanto dos alunos como da direção, mas que acredita que essa experiência também irá agregar em seu dia a dia em sala de aula.

Os professores A e C veem como algo que irá agregar lá na frente no retorno às aulas presenciais. É importante nos recordamos das respostas anteriores, nas quais ambos relatavam as dificuldades por não terem tido uma formação para exercer tal atividade. E o professor $B$, o único que alega ter formação para trabalhar a educação remota, mesmo assim, ao fim da pesquisa, demonstra ainda uma resistência à implantação dessas tecnologias em seu dia a dia em sala de aula.

No posicionamento do professor $B$, podemos destacar a sua insatisfação com essa modalidade de ensino, quando ele recorre ao discurso legitimado academicamente, ao citar o estudioso da linguagem 
Bakhtin: "Os textos são sujeitos com ideologias, intenções, história, sentimentos; são sujeitos que tomam decisões; sujeitos que requerem posicionamentos de quem os lê, conforme aprendemos com Bakhtin". Segundo este professor, o novo formato de ensino está tirando isso dos alunos e dos professores também.

Acerca da necessidade de incorporação das tecnologias no ensino remoto, a professora e pesquisadora Ana Elisa Ribeiro (2020) explica:

Diante desse cenário, as tecnologias digitais passaram a ser vistas, por alguns/mas, como 'salvação', na medida em que poderiam dar continuidade, ainda que improvisada e até inadequadamente, ao ano letivo, obviamente à custa do sacrifício extremo de professores/as e gestores/as, pressionados por todos os lados. Por outros, as mesmas tecnologias passaram a ser vistas como 'vilãs', em específico, porque ampliariam as desigualdades entre estudantes conectados e desconectados, escolas menos e mais equipadas, professores/as menos e mais preparados/as, evidenciando assim o fosso entre camadas sociais e escolas menos e mais equipadas e qualificadas (RIBEIRO, 2020, p. 03).

Diante dessa citação, que revela muito de como se formou essa nova modalidade de ensino às custas de sacrifício de professores e gestores, com a implementação da tecnologia, por todos os efeitos controversos que ela tem causado e por não ter sido implantada anteriormente com a grandiosidade que ela pode proporcionar, tem adquirido grande resistência por parte dos docentes.

Quanto à professora que optou a se abster de participar da pesquisa, ao justificar que está muito atarefada e sobrecarregada, entendemos que sua resposta acaba por revelar e confirmar as respostas dadas pelos demais professores, os quais estão trabalhando em regime de quase 24 horas por dia, conforme advertem os professores A e C, quando alegam que "a todo momento chegam notificações de alunos no celular". Discursos como esses revelam o desabafo dos docentes diante do contexto de ensino remoto, inclusive a insatisfação com os poderes governamentais por não valorizarem e reconhecerem os esforços que esses profissionais vêm realizando para conseguir efetivar essa jornada.

\section{CONSIDERAÇÕES (QUE NUNCA SÃO) FINAIS}

Ao final dessa pesquisa, concluímos que o trabalho no ensino de Língua Portuguesa voltado para práticas de Multiletramentos e Letramentos na escola é um campo fecundo para atuação em discussões e na permissão de aprimoramento tanto teórico quanto prático no que tange às práticas sociais da leitura e da escrita realizadas nos diversos suportes (impresso e digital) e em suas diversificadas linguagens (escrita, visual, digital). 
A cultura digital tem nos propiciado novas formas de pensamento e de compreensão da realidade e consequentemente de como se efetiva a interação dos indivíduos. 0 ciberespaço vem possibilitando o surgimento de diversificados tipos de multiletramentos e tem provocado mudanças sociais no que se refere às práticas de leitura e escrita e ao que se espera em termos de informação, ensino e aquisição de novos conhecimentos.

Dessa forma, as práticas de ensino multiletradas necessitam que os professores tenham esse domínio sobre elas, tanto dentro como fora das salas de aula, e, para que se tenha domínio sobre a utilização das TICs, o nosso corpo docente precisa de formação, no intuito de que possam acompanhar as demandas sociais que vêm surgindo e de que possamos trazer essa virtualização cada vez mais para o âmbito escolar.

A partir do formulário respondido por esses docentes, podemos perceber que efetivar a educação por meio de ferramentas digitais tem sido o maior desafio enfrentado por esses professores e, dentro da perspectiva dos multiletramentos, é imprescindivel a necessidade da inserção desses professores nas dinâmicas de utilização dos espaços virtuais para o ensino. Não apenas como mais um instrumento de aprendizagem, mas sim como uma necessidade da implantação da democratização dos bens culturais digitais a serviço da autonomia dos estudantes.

De modo geral, os resultados evidenciam o quanto esse trabalho é importante e nos guiam ainda para entendermos o que esses profissionais vêm sentindo com a nova forma de ensinar a eles imposta, mostram ainda que mesmo que tenham enfrentado dificuldades quanto à implementação dessa nova forma de ensinar em suas carreiras, esses docentes em sua maior parte acreditam que tenha sido uma experiência difícil, mas que trará pontos positivos, pois através dela o que antes não era usado como ferramenta de ensino em sala de aula pode vir a agregar em suas formas de trabalhar.

Evidenciamos aqui que em nenhum momento dessa investigação pretendemos julgar as práticas de cada um aqui exposta como certas ou erradas, muito menos desqualificar a opinião que cada um tem acerca das formas de lecionar. Além disso, acreditamos que se adequar a essas tecnologias seja um processo e, como todo processo, no caminho encontraremos percalços, porém que se essa caminhada for trilhada com empenho, dedicação e sérias políticas públicas formativas, conseguiremos chegar em um denominador comum para atender às necessidades das nossas escolas e professores. Precisamos que nossos governantes voltem seu olhar para essa classe que tem se reinventado a cada aula remota para levar conhecimento. 


\section{REFERÊNCIAS}

ALBUQUERQUE. E. B. C. Conceituando alfabetização e letramento. Organizado por Carmi Ferraz Santos e Márcia Mendonça. 1. ed. 1. reimp. Belo Horizonte: Autêntica, 2007. 152 p. ISBN 85 - 752 -161-41.

BAKHTIN, Mikhail M. Problemas da poética de Dostoiévski. Tradução do russo, notas e prefácio de Paulo Bezerra. 4. ed. Revista e ampliada. Rio de Janeiro: Forense Universitária, 2003.

BAKHTIN, Mikhail M. O problema do texto na linguística, na filologia e em outras ciências humanas. In: BAKHTIN, Mikhail. Estética da criação verbal. 6. ed. São Paulo: Martins Fontes, 2011.

BARTON, David; LEE, Carmen. Linguagem online: textos e práticas digitais. Tradução Milton Camargo Mota. 1. ed. São Paulo: Parábola Editorial, 2015.

BRAIT, Beth. Olhar e ler: verbo-visualidade em perspectiva dialógica. Backhtiniana, São Paulo, 8 (2): $43-$ 66, jul./dez. 2014. Disponivel em: http://www.scielo.br/pdf/bak/v8n2/04.pdf. acesso em: 07 nov. 2020.

BRAIT, Beth. Baktin: conceitos-chave. 5. Ed. 6. Reimpressão. São Paulo: Contexto, 2020.

BRASIL. Base Nacional Comum Curricular. Brasilia: MEC, 2018. Disponivel em: http:// basenacionalcomum.mec.gov.br/images/BNCC_EI_EF_110518_versaofinal_site.pdf. Acesso em: 25 ago. 2020.

COSCARELLI, Carla. Tecnologias para aprender. 1. ed. São Paulo: Parábola Editorial, 2016.

DELORS, J. Educação: um tesouro a descobrir. 8. ed. São Paulo: Cortez; Brasília, DF: MEC: UNESCO, 2003.

FARACO, C. A. Criação ideológica e dialogismo. In: FARACO, C. A. Linguagem e diálogo: as ideias linguísticas do Círculo de Bakhtin. São Paulo: Parábola Editorial, 2009. p. 45-97.

MARTINS et al. Multiletramentos na pandemia: aprendizagens na, para a e além da escola [recurso eletrônico e-book]. São Leopoldo, Casa Leiria, 2021.Disponível em: http://guaritadigital.com.br/ casaleiria/acervo/educação/multiletramentosnapandemia/index.html. Acesso em: 25 ago. 2020.

ROJO, Roxane. Escol@ conectada: os multiletramentos e as TICs. São Paulo: Parábola Editorial, 2013.

ROJO, Roxane. Letramentos múltiplos, escola e inclusão social. São Paulo: Parábola Editorial, 2009. 


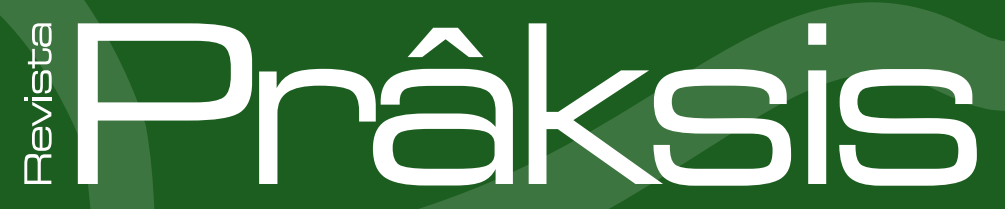

ROJO, Roxane, MOURA, Eduardo. Letramentos, mídias, linguagens. São Paulo; Parábola Editorial, 2019. MINAYO, Maria Cecília de Souza (org.). Pesquisa Social. Teoria, método e criatividade. 18. ed. Petrópolis: Vozes, 2001.

TEZZA, Cristóvão. Sobre 0 autor e o herói - um roteiro de leitura. In: FARACO, Carlos A.; TEZZA, Cristovão; CASTRO, Gilberto (Org.). Diálogos com Bakhtin. Curitiba: Editora da UFPR, 2001.

VOLOSHINOV, V. N. Qué es el lenguaje? Tradução do italiano de Ariel Bignami. In: SILVESTRI, A.; BLANCK, G. Bajtín y Vigotsky: la organización semiótica de la conciencia. Barcelona: Anthropos, 1993. 